University of Nebraska - Lincoln

DigitalCommons@University of Nebraska - Lincoln

Agronomy \& Horticulture -- Faculty Publications

Agronomy and Horticulture Department

4-1932

\title{
Indicator Significance of Brush Lands for the Growth of Western Yellow Pine
}

J. E. Weaver

University of Nebraska-Lincoln

Follow this and additional works at: https://digitalcommons.unl.edu/agronomyfacpub

Part of the Plant Sciences Commons

Weaver, J. E., "Indicator Significance of Brush Lands for the Growth of Western Yellow Pine" (1932).

Agronomy \& Horticulture -- Faculty Publications. 462.

https://digitalcommons.unl.edu/agronomyfacpub/462

This Article is brought to you for free and open access by the Agronomy and Horticulture Department at DigitalCommons@University of Nebraska - Lincoln. It has been accepted for inclusion in Agronomy \& Horticulture -Faculty Publications by an authorized administrator of DigitalCommons@University of Nebraska - Lincoln. 
Indicator Significance of Brush Lands for the Growth of Western Yellow Pine

A study of unusual interest and significance in the application of ecological principles to the solution of an economic problem has recently been completed. ${ }^{1}$ It deals with the causes for the absence of western yellow pine in l)rush vegetation of various types that occur throughout the mountainous portions of northern Utah, eastern Idaho, and western Wyoming, and, in fact, form a much interrupted and fragmented belt whose center extends from the Gulf of California to west-central Montana. Many of these brush sites, especially in northern Utah and southern Idaho, lie immediately below the Douglas fir type (which is continuous) and would normally be expected to support yellow pine, since they have the same elevation as pine clad areas in other parts of the West. An attempt to improve the brush cover by the planting of pines during a 5-year period ended in failure and led to the present investigations. They were conducted with the idea of determining the feasibility of planting pines, and thus extending the natural range of the forest, and of discovering means whereby areas suitable for the growth of pine could be determined.

A study was made to determine the characteristics of climate and soil in the brush lands, especially those lying between northern Utah and southeastern Idaho, and to compare them with conditions prevailing where the pines grew naturally. Temperature, although a potent factor in determining distribution

${ }^{1}$ Baker, F. S., and C. F. Korstian, I931. Suitability of brush lands in the intermountain region for the growth of natural or planted western yellow pine forests. $U$. $S$. Dept. Agri. Tech. Bull., 256. 
of species in mountainous regions, does not explain the peculiarities of the pine on both sides of the brush-land belt. There is apparently a broad zone extending from the base of the near-by forested mountains to intermediate elevations covered with brush. Nor are there notable differences in total annual precipitation, which obviously is not the controlling factor in the plant distribution. The distribution of the precipitation during the summer months in the brush lands is, however, very different from that either to the north or the south. "May precipitation within the temperature zone suited to western yellow pine is ample for the reproduction of this species. In the pinelands to the south, the July and August precipitation, which greatly exceeds that in the brush lands, is ample for the reproduction of western yellow pine. In the intervening brush lands the light character and brief duration of May rain, coupled with the extremely dry June that quickly follows, prevents the establishment of the reproduction in the early spring. Deficiencies in July and August precipitation, combined with the fact that the rainfall usually culminates in August shortly before the early autumn frosts occur, make it impossible for the species to reproduce."

Although the distribution of the rainfall determines the general limits of the pine lands, the details of its boundaries are chiefly the results of local differences in soils. In general, the lighter types of soil are more favorable to the pines and especially so near the edge of their range, the pines spreading far from the main bodies of forest on sandy soils and along streams. The brush lands, in general, are characterized by calcareous, heavy, fine-grained soils and are prevailingly unsuitable for the growth of the pine. Unfortunately, data on climatic and edaphic factors in the brush lands and forests of this vast area are meager, but those available are convincingly presented.

In a second line of study, seedlings of the pine were transplanted under different conditions in the brush-land areas, since it is well known that planted stands often develop normally in regions where natural regeneration is impossible. Plantations were established in the brush belt in central, western, and northern Utah and also in southern Idaho. The effects on the transplants of soil moisture, soil texture, rate of evaporation, and shade were all carefully considered as well as injury by rabbits.

It was conclucled that the establishment of artificial stands by planting is rendered extremely difficult by the same factors of rainfall that operate so powerfully against the natural reproduction of this species that the pine can not naturally invade the permanent brush lands. In fact, success in planting generally occurred only on sites with unusually favorable water content, and conspicuous success was attained only in seasons of exceptionally heavy spring rainfall. Moreover, suitable sites are not easily selected in average years, for they generally bear such a luxuriant cover of brush that failure of the seedlings due to shade is almost certain.

Attention was thus naturally directed to the use of the various native shrubs as indicators of desirable planting sites. Their natural succession, 
root development, and leaf characters were extensively studied. A brief statement of the succession on wet and dry lands, and also the effect of fire is given. It is emphasized that the brush lands are the climatic climax and not subclimax vegetation resulting from repeated fires. Excellent sketches of the root systems of the pine and $2 \mathrm{I}$ of the most important shrubs are given, illustrating four general root types, viz.: deeply rooted species with taproots and practically no feeding roots in the upper layers; species with widely spreading rhizomes with a shallow network of roots and a deep-feeding root system; generalized root system; and 2-storied systems with practically no feeders in the intermediate soil layers.

In selecting planting sites not only soil moisture and root competition but also the degree of shade must be considered. A study of the vegetation on the ground enables all three factors to be evaluated with a fair degree of accuracy. The presence of shallow rooted species absorbing mainly in the surface soil indicates that the pines must be planted in direct competition with the native vegetation. Such sites are unsuitable for planting. "The best results can be obtained with plantations on sites where absorbing roots of the native vegetation are found at depths below 2 feet and where the trees can safely be placed close to the north side of the bushes where the shade will serve to reduce evaporation and transpiration. Such sites are likely to be naturally severe, as deep-feeding shrubs tend to occupy dry sites. Therefore. in most cases such sites should be selected for forest plantations only when they are otherwise naturally suitable." "If the native vegetation can be removed before planting, sites which originally supported a vegetation composed of shallow-rooted species will prove the most satisfactory. . . ."

The study of leaf characters included leaf size, structure, water content. relative transpiration, and sap density. These were made with the purpose of extending the usefulness of the native shrubs as indicators of planting sites by showing which deeply rooted species, as heavy users of water, may indicate areas where there is sufficient water available for western yellow pine. Although " there is no satisfactory way of summarizing all these factors so that their resultant effect is evident, for their relative importance is still largely unknown," yet with the aid of these criteria (including root characters and crown (lensity) it is possible to select suitable sites for planting in the brush lands. A species should not be planted on any site where the native vegetation possesses uniformly higher sap densities than those generally maintained by the planted species cluring the dry season. "Contrary to an earlier belief, the brush lands are fundamentally unsuited to the natural reproduction of western yellow pine. . . . Moreover, there is no evidence that stands artificially established will maintain themselves or spread naturally as originally expected." "Only a portion of the brush lands can be classed as suitable planting sites, and the best sites, covered with deep-rooted, thinfoliaged shrubs on northern exposures, are rare." Cleared or burned sagebrush areas may show fair success; the remainder of the sites are inferior. 
Hence, extensive planting in the permanent brush lands of the intermountain region is not justified.

This extensive research adds much to the ecology of the great intermountain region and is an excellent contribution to the important subject of plant indicators.

UNIVERSITY OF NEBRASKA,

J. E. WeAver

LinCOLN, Nebr. 